\title{
A TEORIA DA ESCOLHA \\ RACIONAL NA CIÊNCIA POLÍTICA: \\ Conceitos de racionalidade \\ em teoria política*
}

\author{
John Ferejohn e \\ Pasquale Pasquino
}

\section{Introdução ${ }^{1}$}

Teorias da escolha racional de vários tipos tiveram um impacto enorme na forma como a Ciência Política foi desenvolvida, ao menos nos Estados Unidos. Até o momento, entretanto, esse impacto tem se limitado, em grande medida, às partes mais empiricamente orientadas da disciplina, principalmente os estudos de política americana, relações internacionais e política comparada. Normalmente, teorias da escolha racional são definidas como positivas, em oposição a teorias normativas. O principal objetivo das primeiras é desenvolver teorias preditivas bem-sucedidas em Ciência Política.

$\mathrm{Na}$ sua maior parte, a teoria da escolha racional entrou na Ciência Política a partir da Economia, como resultado dos trabalhos pioneiros de Anthony Downs, James Buchanan, Gordon Tullock, George Stigler e Mancur Olson. Embora esses autores possam ter discordado em inúmeros

* Conferência proferida no XXIII Encontro Anual da Anpocs, Caxambu, MG, outubro de 2000.

Tradução de Eduardo Cesar Marques. aspectos entre si, todos adotaram uma interpretação particularmente materialista da teoria da escolha racional. Para todos eles, os agentes sociais estariam interessados na maximização da riqueza, de votos, ou de outras dimensões mais ou menos mensuráveis em termos de quantidades e sujeitas a constrangimentos de recursos materiais. Todas as teorias resultantes se estruturam da mesma forma: as escolhas feitas pelos agentes devem ser explicadas em termos da variabilidade dos constrangimentos materiais enfrentados por eles. Essa visão, que podemos chamar de "externalista", constituise em uma metodologia eficiente de construção de uma ciência social positiva. Mas ela não exaure a relevância da racionalidade na Ciência Política.

Na verdade, acreditamos que a situação atual é duplamente irônica. Em primeiro lugar, as próprias teorias da escolha racional são mais bem classificadas como teorias normativas do que como teorias positivas. Ninguém realmente acha que os seres humanos reais se comportam exatamente como as teorias da escolha racional prescrevem. E isso não se deve a desvios ocasionais ou erros. As evidências experimentais existentes em grande abundância sugerem que as pessoas se desviam sistematicamente das predições da teoria da esco- 
lha racional. Ainda assim, mesmo não agindo racionalmente, as pessoas tendem a reconhecer a força normativa da racionalidade, e isso influencia as suas ações - que se aproximam ao menos um pouco daquilo que criaturas de racionalidade ideal fariam nas mesmas circunstâncias.

Em segundo lugar, como sustentaremos no presente artigo, teorias políticas normativas apóiam-se fundamentalmente em suposições de racionalidade. Assim, parece-nos especialmente interessante que as teorias da ação racional como as discutidas aqui não tenham avançado muito entre teóricos normativos da política. ${ }^{2}$

Acreditamos que essa separação entre teoria normativa e teoria positiva é não apenas estranha mas, pode-se sustentar, de origem bastante recente, especialmente quando se considera a longa história da teoria política. Ao longo deste artigo vamos sustentar que, tradicionalmente, teóricos políticos adotaram pressupostos de racionalidade, ao menos implicitamente, por duas razões interrelacionadas. Em um primeiro nível, teorias normativas são endereçadas a agentes racionais, preocupados com a crítica de práticas correntes ou com o estabelecimento de novas. O teórico interessado em persuadir uma audiência que se presume que responde à razão a inclui em sua visão a respeito de arranjos sociais e políticos. O objetivo do teórico é nos convencer de como a vida política deveria ser vivida, e tentando fazer isso nos trata como capazes de acompanhá-lo na contemplação de como as instituições alternativas ou os sistemas normativos iriam funcionar.

Em um outro nível, a teoria normativa trata com (ou contém) sujeitos racionais ou inteligíveis, cujas ações podem ser entendidas ou talvez alteradas pela mudança do seu contexto institucional. A racionalidade é, nesse sentido, um ponto de partida inescapável para uma teoria normativa. As instituições políticas e sociais são formas de regular ou direcionar as atividades de pessoas que são capazes de responder de forma previsível a seus comandos. A tentativa de criar uma vida pública através do desenho de instituições e normas pressupõe a capacidade das pessoas de responder de forma minimamente racional a suas diretrizes, o que não implica, é claro, que as pessoas reais sejam perfeitamente racionais. Além disso, se é possível construir uma psicologia na qual as irracionalidades possam ser modeladas, as instituições podem ser úteis em canalizar também o comportamento irracional. Ao longo deste texto veremos alguns exemplos disso, mas as formas pelas quais os teóricos modelaram irracionalidades — as paixões, por exemplo - não as torna necessariamente desvios da racionalidade do ponto de vista técnico. Fazer alguma coisa por causa de uma paixão não significa a inexistência de cálculos entre meios e fins. Na verdade, o apelo a uma visão normativa para uma audiência apóia-se, em grande parte, na capacidade dessa audiência de se colocar no interior do quadro geral produzido pela teoria e de ser persuadida de que poderia agir da forma como a teoria prevê.

Sob um certo ponto de vista, já existe uma conexão próxima entre os projetos normativo e positivo na teoria política. Quem prescreve uma ação deve ser capaz de antecipar suas conseqüências relevantes em termos normativos. Em termos de definição, isso se aplica a teorias conseqüencialistas, mas nós acreditamos que teorias não-conseqüencialistas também precisam fazer cálculos dessa natureza, de forma a construir justificativas para o seu conteúdo moral. Por exemplo, para que um kantiano decida se um ato satisfaz o princípio da universalização, ele precisa imaginar as conseqüências, para uma dada pessoa, de agir em uma situação hipotética. Nesse sentido, qualquer teoria normativa requer uma teoria positiva que permita desenvolver os cálculos apropriados das ações. Além disso, para que uma teoria normativa seja atrativa, ela deve ser ao menos um pouco plausível, assim como atrativa, à luz da teoria positiva. Ela deve conseguir acertar (ao menos na maior parte das vezes), caso contrário qual seria a atração das prescrições normativas que se apóiam nela?

Por essas razões, portanto, teorias da ação racional, de um tipo ou de outro, podem prover fundações particularmente úteis para o pensamento normativo. Para alguns pensadores, a razão é uma capacidade humana distintiva, e ser inteiramente humano é ser inteiramente racional. Para esses autores, mesmo se todos tiverem capacidade de agir racionalmente, a ação racional completa 
seria uma conquista alcançável apenas por alguns. Para os que têm essas capacidades menos desenvolvidas, somente graus menores de racionalidade podem ser alcançados. Para outros autores, racionalidade é uma capacidade comungada por cada agente humano e também, em menor grau, por alguns animais. Em ambos os casos, uma capacidade racional mínima - normalmente denominada de racionalidade instrumental — é universalmente distribuída. Além disso, teorias da escolha racional têm se mostrado relativamente maleáveis, permitindo aos teóricos descobrir as conseqüências da adoção de normas e instituições pelos agentes racionais. Obviamente, os desenvolvimentos teóricos modernos sugerem que a maleabilidade teórica não é idêntica à transparência, mas permanece como elemento vital na produção de conselhos normativos convincentes.

Entretanto, as concepções de racionalidade que são encontradas em textos históricos são de alguma forma diversas se observadas de um ponto de vista moderno, e parece ser proveitoso recuperar essas idéias, ao menos por duas razões. Em primeiro lugar, aplicando avanços técnicos em teoria da decisão e teoria dos jogos, pode ser possível investigar mais profundamente as teorias normativas desenvolvidas por tais pensadores. Utilizando a expressão de Greg Kavka (1986), essas explorações entrarão no pensamento de Hobbes, se não na própria teoria de Hobbes. Em segundo lugar, podemos vir a encontrar em conceitos antigos de racionalidade algumas idéias de racionalidade que tenham sido desconsideradas ou esquecidas no curso do desenvolvimento moderno. Influenciados pelos economistas, vários cientistas políticos simplesmente identificaram racionalidade com o que chamamos de racionalidade instrumental. Nós acreditamos que essa identificação nos cega para concepções mais amplas de racionalidade presentes na ciência e na teoria política por mais de dois milênios. A teoria da escolha racional não é uma aquisição recente do pensamento político, mas tem feito parte dele desde os gregos.

De qualquer forma, parece valer a pena iniciar o diálogo com esses pensadores antigos. Neste artigo, examinaremos três pensadores de importância especial: Aristóteles, Hobbes e Rousseau. Sustentamos que eles empregaram centralmente conceitos de racionalidade em suas teorias, em termos bastante modernos.

Obviamente, não podemos resenhar aqui todos os esforços primordiais de teoria normativa, e portanto podemos prover apenas um rápido esquema dos argumentos que podem apoiar nossas afirmações. Optamos pela escolha de alguns teóricos particularmente importantes - Hobbes, Aristólteles e Rousseau - em cujas teorias algum argumento da escolha racional ocupou um lugar central. Poderíamos ter escolhido Hume, Locke ou Madison ao invés de Hobbes, e provavelmente Platão serviria quase tão bem quanto Aristóteles. Ao invés de Rousseau, poderíamos ter escolhido Kant ou qualquer teórico democrático mais moderno. A nossa escolha foi baseada na centralidade da racionalidade nas suas teorias, assim como na facilidade de sua delimitação.

\section{Racionalidade}

Empregamos uma definição mínima de ação racional: convencionalmente, um ato racional é um ato que foi escolhido porque está entre os melhores atos disponíveis para o agente, dadas as suas crenças e os seus desejos. Atos racionais maximizam preferências ou desejos, dadas determinadas crenças. Colocado de outra forma, a racionalidade requer que crenças, desejos e ações se relacionem de uma forma particular. Nesse sentido, a racionalidade é uma condição de consistência que sustenta que essa relação seja válida para todas as crenças, desejos e ações.

A interpretação psicológica tradicional dessa definição é que os agentes têm estados mentais crenças e desejos - e escolhem as melhores ações que estejam de acordo com eles. Os desejos são considerados de alguma forma como dados ou definidos previamente às ações e também às crenças. Os desejos podem ser, dependendo da teoria, ancorados em necessidades humanas mais profundas (comida, sexo, segurança), ou podem ser ligados à posição social, ou a atitudes morais, ou podem simplesmente ser arbitrários. O ponto é que eles são de alguma forma fixos ou definidos 
antes da escolha da ação. São os desejos ou as preferências que serão satisfeitos na escolha.

As crenças são comumente pensadas como ancoradas de alguma forma na realidade concreta. Supõe-se que as crenças, ao menos a respeito de constrangimentos físicos ou naturais, assim como sobre as conseqüências naturais da ação, são em sua maior parte verdadeiras. É uma outra questão, que enfrentaremos mais adiante, se as crenças sobre a forma como as outras pessoas vão agir são constrangidas e, caso sejam, como se supõe que elas sejam constrangidas. De qualquer forma, supõe-se que crenças, assim como desejos, sejam anteriores à escolha e à ação. Se consideramos um triângulo de crenças, desejos e ações, a única coisa que fica livre para variar é a ação. A agência consiste na escolha das ações à luz das crenças e dos desejos. Nós chamaremos isso de Interpretação I.

Mas também poderíamos supor que as crenças estão ancoradas na verdade (como antes) e as ações são determinadas, por exemplo, por algum conjunto externo de requisitos morais e éticos, ou talvez por algum processo neuropsicológico ao qual o agente tem acesso apenas parcial. A seguinte situação exemplifica o caso: "Esta", pode-se supor, "é a forma pela qual uma boa ateniense deveria agir". Então, de acordo com a Interpretação II, uma boa ateniense, se ela fosse racional no nosso sentido, buscaria formas de ajustar os seus desejos de maneira a almejar algo que uma boa ateniense iria almejar. É claro que ela pode não fazer isso se rendendo à racionalidade, e fazer a coisa certa simplesmente porque é a coisa certa. Kant talvez pudesse concordar com essa forma de comportamento, mas é duvidoso que Aristóteles e outros gregos o aceitassem. Um exemplo menos normativo pode ser dado: suponha que você gosta de sorvete e considera o de chocolate o seu favorito. Mas depois de um certo tempo, fica claro que quando há escolha, você tende a ficar com o de baunilha ao invés do de chocolate (talvez, nas circunstâncias de escolha reais, o sorvete de baunilha acione certas "campainhas mentais" que o de chocolate não alcance). Você pode então descobrir que, em uma circunstância como essa, a sua preferência real segue o seu comportamento de escolha. Essa é uma versão da história da preferência revela- da, mas aqui a sua preferência (tomada como um estado mental consciente) é "construída".

Já podemos vislumbrar a chegada da Interpretação III. Podemos tomar as ações e os desejos como dados, e tentar ajustar as crenças. Admitimos que essa é uma postura difícil se estamos falando de crenças a respeito da natureza que podem ser facilmente refutadas (embora o pensamento mágico dê espaço para alguma manobra, mesmo aí). Mas no que diz respeito a outros tipos de crenças, essa estratégia é similar aos esforços de Pascal para se convencer da existência de Deus. O bom comportamento era prescrito externamente, e pode-se considerar que os seus desejos estavam em grande parte fora do seu controle consciente. Mas ele pensou que poderia encontrar formas de mudar as suas crenças de maneira a conseguir escolher livremente uma vida devota (dadas essas crenças e os seus desejos).

Você gostaria de adquirir fé e não sabe o caminho. Você gostaria de se curar da descrença e pede um remédio para isso. Aprenda com aqueles que, como eu, foram limitados como você, e que agora põem em risco todas as suas posses. Essas são pessoas que sabem o caminho que você deverá trilhar, e que foram curadas de um mal de que você também será curado. Siga o caminho que elas tomaram, agindo como se acreditasse, tomando a água benta, freqüentando a missa etc. Até mesmo isso o fará naturalmente acreditar, e amortecerá a sua perspicácia. (Pascal, Pensamentos, 233)

Este tipo de pensamento mágico (ou de psicologia profunda) pode parecer especial demais para ser de grande interesse para nossos propósitos. Então, para tornar a interpretação mais familiar, apresentaremos outros exemplos (mais mundanos) nos quais a ação pode dar forma às crenças no sentido sustentado por Pascal. ${ }^{3}$

O exemplo natural é a teoria das expectativas racionais. Nessa teoria, supõe-se que as crenças se mostrem verdadeiras, ou ao menos consistentes com as informações observáveis pelos agentes. Mas, de uma forma geral, várias crenças diferentes serão "racionais" nesse sentido, induzindo os agentes a fazer escolhas que as confirmem. Um exemplo 
trivial é o de um jogo de coordenação pura, no qual as pessoas poderiam dirigir do lado esquerdo ou do lado direito da rua. Nesse caso, há dois equilíbrios estratégicos puros - todos dirigem pela esquerda ou todos dirigem pela direita - e em cada equilíbrio as pessoas formam crenças verdadeiras sobre o lado da estrada no qual os outros vão dirigir. Estas tornam-se crenças a respeito do equilíbrio que está em vigência. No equilíbrio "do lado direito", cada agente acha que as pessoas estão dirigindo pela direita e por isso dirige também pela direita, assim como todos os demais. Então, a crença é verdadeira nesse equilíbrio. Note-se que as crenças aqui não são a respeito da natureza, mas a respeito de que tipo de comportamento as outras pessoas vão seguir.

É fácil encontrar exemplos que envolvam crenças naturais, assim como apoiar a idéia de que é custoso fazer observações. Suponhamos, por exemplo, que o agente acredita que não se encontrará petróleo ao longo da costa de San Francisco e que é custoso descobrir se isso é verdade ou nãoé. Então, é bem possível que o agente não procure petróleo, já que ele acredita que não se encontrará nada, e que a sua crença seja falsa. Em ambos os exemplos, é possível vislumbrar o processo pascaliano de formação da crença: você justifica não perfurar nos lugares em que provavelmente não há nenhum petróleo. ${ }^{4}$

Apenas para esclarecer, nós não estamos afirmando em nenhum dos dois últimos casos que as pessoas estão escolhendo as suas preferências ou que elas estão escolhendo as suas crenças. As preferências e as crenças são, em ambos os casos, interpretadas ou construídas, apoiadas ou adotadas. O agente entende que está comprometido a alcançar um objetivo, que isso é parte do seu projeto de vida. Esse processo é, em parte, um reconhecimento ou uma descoberta (e portanto interpretativo), mas também é parcialmente uma aceitação (e uma adoção). Como no primeiro caso — instrumental —, as preferências e as crenças se encaixam com cada escolha de uma forma consistente. Esse requisito de consistência é na verdade o que permite a inferência ou construção. Ambos os exemplos, entretanto, abrem um caminho para o entendimento da persuasão e/ou da moldagem externa desses conceitos supostamente mentais: preferências e crenças. Pensamos que é essa faceta que as torna particularmente interessantes para os teóricos normativos.

Examinamos agora partes de três teorias da política em uma ordem grosseiramente ascendente de "dificuldade", começando com Hobbes e prosseguindo para Aristóteles e Rousseau. Cada qual apresenta exemplos de teoria da escolha racional, no sentido amplo que avançamos anteriormente, $\mathrm{e}$ cada teoria pode ganhar pelo contato com os avanços modernos. Há algo, portanto, para os teóricos normativos aprenderem com a teoria da escolha racional, mas, da mesma forma que a teoria ética-política de Aristóteles ou a teoria do contrato social de Rousseau são reconhecíveis como variantes da teoria da escolha racional, acreditamos que os teóricos da escolha racional também podem aprender dela.

\section{Hobbes e a racionalidade instrumental}

O projeto de Hobbes no Leviatã era justificar a obediência por parte de súditos a um soberano absoluto, tendo como único ou predominante interesse a sua autopreservação. Em uma certa medida, esse projeto apóia-se em dois julgamentos táticos. Primeiramente, se a obediência a um soberano absoluto pode se justificar, então a obediência a quem detém poder também se justifica. Em segundo lugar, se os súditos que têm como único interesse a autopreservação podem ser persuadidos de que eles têm um dever de obediência, então os súditos com automotivações menores também terão de reconhecer esse direito. Então, Hobbes necessita mostrar duas coisas: primeiro, que a obediência era um dever para as pessoas interessadas na autopreservação e, segundo, que o principal interesse de todos é a autopreservação. Grande parte do Leviatã se ocupa do primeiro projeto. O segundo, que é realmente um problema mais retórico do que dedutivo, não foi enfrentado diretamente. Em todo caso, parece claro que Hobbes pensava que embora as pessoas pudessem não ter clareza sobre quais eram os seus reais interesses muitos estavam arriscando as suas vidas em confli- 
tos religiosos -, elas realmente tinham interesses ou preferências fixados a priori, e se pudessem descobri-los iriam agir a partir deles de maneira racional.

Estabelecendo sua famosa solução, Hobbes afirmou que a obediência a um soberano era um dever, já que a alternativa - a vida em um estado de natureza - era horrível. ${ }^{5}$ Hobbes afirmou que a vida em um estado de natureza é um estado de guerra de todos contra todos e seria "solitária, pobre, má, embrutecida e curta”. Ele explica que em um estado de natureza

[...] não há espaço para o trabalho industrioso, porque os seus frutos seriam incertos: e conseqüentemente não haveria cultura da terra, não haveria navegação, nem mesmo o uso de produtos que tenham que ser importados por mar; também não haveria edificações cômodas [...] nem artes, nem letras, nem sociedade; e o que é pior de tudo, haveria pânico e medo continuado da morte violenta [...] ( Leviatã, cap. 13 [62])

Por medo da perda de sua vida e de suas possessões, os agente hobbesianos não investiriam na criação de riqueza ou cultura, mas viveriam uma vida de permanente estado de pobreza espiritual e material.

[...] onde um invasor não tenha mais o que temer a não ser o poder unitário de outro homem, se alguém plantar, costurar, construir ou possuir um assento conveniente, pode-se esperar que outros venham com forças unidas para tomar suas posses e privá-lo, não apenas dos frutos do seu trabalho, mas também da sua vida e da sua liberdade. (Leviatã, cap. 13 [61])

Hobbes afirma que essa descrição é dedutível da sua descrição do estado de natureza e da sua caracterização da psicologia humana. Crucial para o seu argumento é a afirmação de que os agentes, agindo racionalmente, não formariam grupos de defesa mútua que os permitissem criar e manter com segurança a riqueza criada no estado de natureza. Um grupo de comentadores recentes tem discordado dessa afirmação, sustentando, essen- cialmente, que a vida em um estado de natureza poderia não ser tão ruim como na descrição de Hobbes. ${ }^{6}$ Alguns analistas, por exemplo, sugerem que os agentes hobbesianos no estado de natureza racionalmente fariam e sustentariam acordos de vantagens mútuas, com o propósito de produção e defesa, e conseqüentemente o estado de anarquia seria mais parecido com o estado de natureza de Locke (relativamente benigno) do que a situação bestial descrita por Hobbes. Obviamente, se essa visão for válida, as conclusões de Hobbes a respeito da possibilidade de os indivíduos no estado de natureza concordarem com a criação de uma autoridade política e, se concordassem, sobre o tipo de Estado a ser criado são bastante fracas. Por que pessoas que podem coordenar as suas atividades produtivas e defensivas com sucesso precisariam de um Estado, ainda mais investido de autoridade absoluta? Se essas pessoas concordassem com a criação de um Estado, apesar de tudo, por que elas não tratariam de limitar cuidadosamente os seus poderes para que ele não invadisse seus domínios privados? Por que não condicionariam a sua aceitação das reivindicações do Estado ao fato de este ter poderes limitados?

As implicações da cooperação excessiva em um estado de natureza, devastadoras para o argumento de Hobbes, forçaram pesquisadores a reconstruir a psicologia dos agentes hobbesianos, ou a descrever o estado de natureza de uma forma tal que um estado de guerra fosse plausível. Ou então, não conseguindo reconstruí-la, eles admitiram que Hobbes só conseguiria justificar com sucesso uma forma muito mais limitada de autoridade. Embora nós concordemos que a compreensão do argumento de Hobbes para a instituição de um poder absoluto depende dessa reconstrução, não estamos satisfeitos com a argumentação proposta em dois livros excelente sobre Hobbes e o hobbesianismo.

Qual seria a escala dos conflitos existentes no estado de natureza? Tanto Hampton quanto Kavka se preocupam em mostrar que haveria luta real. Não é suficiente para atacar o quadro conceitual de Hobbes, afirma Kavka, que as pessoas não tivessem incentivos para produzir ou possuir bens graças à insegurança que poderia levá-las a perder suas posses ou mesmo as suas vidas. $\mathrm{O}$ autor 
afirma que a vida seria pior e mais insegura que isso e tenta mostrar que no estado de natureza uma guerra "ativa" de todos contra todos prevaleceria. ${ }^{7}$ Hampton baseia a sua explicação sobre o conflito no estado de natureza em uma forma de irracionalidade. A autora argumenta que alguns agentes hobbesianos adotariam um conjunto irracional de crenças, produzindo visão de curto prazo, que levaria a uma recusa em cooperar com outros no estado de natureza, mesmo que a cooperação fosse a solução racional nessas circunstâncias. ${ }^{8}$ Se essa visão curta pode ser uma narrativa plausível da falta de cooperação em sociedades reais, não nos parece adequada como explicação principal na justificativa de uma abdicação incondicional de autoridade para um soberano. Se muitas pessoas têm visão curta, por que não tentar solucionar essa condição diretamente - por exemplo, tentando alterar as crenças estratégicas de uma forma menos draconiana, ao invés de apelar para a solução extrema de abdicar de toda a autoridade para um soberano? A solução de Kavka parece mais plausível. O autor assume que existem algumas pessoas na população, a quem ele chama de dominadores, que valorizam controlar os outros, para além da segurança. Se outras pessoas sabem da existência de dominadores, elas podem ser compelidas a atacar outros antecipadamente, de forma a se prevenirem contra ataques. Os dominadores não são necessariamente irracionais - eles valorizam segurança e escolhem meios eficientes para alcançar os seus fins. Como resultado, eles simplesmente atribuem um valor relativamente mais alto a controlar outros. O problema dessa resposta está no fato de que não está claro, a partir do argumento de Kavka, se eles podem produzir um equilíbrio no estado de natureza. É realmente verdade que, se existem dominadores no estado de natureza, assim como os outros que ele chama de "moderados", existiria um equilíbrio no qual moderados seriam motivados a realizar ataques preventivos contra os indivíduos que eles encontrassem? Há diferença se existirem muitos dominadores ou um pequeno número já seria suficiente?

Do ponto de vista da teoria dos jogos, portanto, a questão que se coloca é se as pessoas no estado de natureza seriam capazes de fazer acor- dos defensivos. A estratégia de Kavka de sustentar a existência de dominadores perigosos e intratáveis parece plausível nos termos em que foi colocada, mas não se sustenta como base para a constituição de uma teoria política persuasiva. Ao fim e ao cabo, se está afirmando que é um fato da psicologia humana que sempre existam pessoas com preferências diferentes, assim como que exista um número suficiente delas para minar a construção de cooperação bilateral. Essas são afirmações empíricas que parecem uma fundação frágil para uma teoria da política. Uma estratégia alternativa seria afirmar que há algo sobre as circunstâncias em um estado de natureza que torna acordos bilaterais difíceis de fazer cumprir. Essa parece ter sido a estratégia preferida de Hobbes.

Para Hobbes, a característica principal da vida no estado de natureza é o fato de que os agentes não podem racionalmente entrar e executar (e conseqüentemente não o farão) o que ele chama de convenções (ou contratos que devem ser executados ao longo do tempo). Os agentes são incapazes de contratar porque cada qual tem medo que o outro não seja capaz de se controlar e quebre as regras. Se é conhecido de todos que os agentes vão quebrar as regras quando isso for do seu interesse, o próprio acordo não tem força de agregação. As palavras de Hobbes sobre isso são inequívocas:

Se uma convenção é feita na qual nenhuma das partes executa nenhuma ação no momento e apenas confiam um no outro, em condições de estado de natureza (que é uma condição de guerra de todos contra todos), quando surge qualquer suspeita razoável o contrato é quebrado [...] ( Leviatã, cap. 14, [68])

Essa condição de "suspeita razoável" é a chave para o entendimento dessa passagem crítica. A questão é se ela funciona para todos os agentes no estado de natureza ou apenas para alguns. Isso é, será que os agentes hobbesianos consideram que qualquer agente racional quebraria o contrato e conseqüentemente todos os contratos estabelecidos no estado de natureza serão provavelmente quebrados, ou será que alguns agentes quebrarão 
o contrato e outros não o farão, e existe alguma forma de distinguir uma situação da outra?

Para responder isso parece ser necessário perguntar o que aconteceria se o contrato fosse mantido. Hobbes considera contratos em que as partes agem de forma seqüencial, e nota que a primeira parte que age racionalmente não manteria o contrato:

Pois aquele que agir primeiro não tem garantia que o outro vá agir depois, já que os laços das palavras são frágeis demais para frear a ambição, a avareza, a raiva e outras paixões humanas sem que haja o medo de um poder coercitivo . Assim, em condições de estado de natureza, [...] não se pode supor que o contrato exista. E portanto, aquele que age primeiro não faz mais do que se trair para o seu inimigo, contrariamente ao seu direito [...] de defender a sua vida e os seus meios de vida. (Leviatã, cap. 14 [68])

O sentido dessa passagem, assim como de inúmeras outras do capítulo 14 do Leviatã, é que apenas as convenções em que há compromisso têm a característica de que, a cada etapa da sua execução, a parte que deve agir acha que é do seu próprio interesse seguir o contrato ao agir.

Quando há um soberano que pode forçar o cumprimento dos acordos, o medo do poder do Estado é suficiente para garantir que cada agente considere racional executar os acordos contratuais. Mas, no estado de natureza, diz Hobbes, a segunda parte a agir será motivada a renegá-los e, sabendo disso, a primeira parte não executará suas obrigações em antecipação a essa possibilidade. Como isso tudo é compreendido no momento da entrada no contrato, nenhuma parte racionalmente concordará com ele, e se concordar com os seus termos, este contrato não será baseado em um compromisso mútuo.

Se isso foi exatamente o que Hobbes quis dizer sobre a questão, parece não haver problemas em compreender suas afirmações sobre a vida no estado de natureza. Os agentes não contratariam no estado de natureza racionalmente porque eles saberiam que os contratos não seriam executados de fato. E como os agentes racionais não entrariam em contratos, aparentemente quaisquer contratos deveriam se basear em alguma forma de irracionalidade e, conseqüentemente, não teriam força de compromisso. O problema, como reconhecem os teóricos de teoria dos jogos, é que essa conclusão não decorre das premissas exatamente dessa forma. Ao menos não é possível compreender a interação repetida no estado de natureza, assim como a observável publicamente, quando as pessoas podem construir e manter reputações de terem comportamento confiável em convenções e acordos. Se as condições de construção de reputação são encontradas no estado de natureza, equilíbrios cooperativos (com contratos bilaterais, por exemplo) existirão.

Na verdade, o próprio Hobbes parece ter tido duas opiniões a respeito disso. No capítulo $15 \mathrm{da}$ edição de 1651 em língua inglesa do Leviatã, em sua famosa resposta aos Tolos, Hobbes lhes disse que, como indivíduos na posição de agir em segundo lugar, deveriam manter as suas obrigações contratuais. Ele nos oferece o que nós hoje podemos reconhecer como um argumento baseado na reputação para essa afirmação:

[...] ele, que declara que considera racional enganar aqueles que o apóiam, não pode racionalmente esperar outra forma de segurança que a que ele tinha do seu próprio Poder singular. Aquele, conseqüentemente, que quebra a convenção, e em conseqüência declara que pode fazer isso com razão, não pode ser recebido na Sociedade, que os une para a Paz e a Defesa, mas pelo erro dos que o receberam [...] ( Leviatã, cap. 15 [73])

Portanto, Hobbes afirma que quem está na posição de segunda parte deveria racionalmente executar o contrato, e isso significa que a primeira parte pode estar segura de que a segunda parte o fará. Dessa forma, a primeira parte aparentemente tem razões para executar a sua parte no contrato e, já que ambas as partes podem antecipar isso, racionalmente, os contratos seriam seguidos. Seria isso apenas um erro? Será que Hobbes mudou de idéia entre os capítulos 14 e 15? Ou será possível reconciliar os dois argumentos? Está aqui, portanto, o quebra-cabeças de Hobbes: se as considera- 
ções relativas à reputação são fortes o suficiente para levar à execução do contrato pela segunda parte, então os contratos são racionais com o objetivo de produção ou defesa, e a vida no estado de natureza não seria necessariamente tão solitária, má, bruta ou curta. Na verdade, se os contratos são suficientemente fáceis (e de baixo custo) para garantir o seu cumprimento por meio da repetição dos jogos, é difícil ver (em termos Coasianos) por que haveria alguma necessidade de criação de autoridade política, no final das contas. Claramente, a afirmação de Hobbes de que agentes racionais no estado de natureza autorizariam um soberano racional é colocada em risco por essa conclusão. Um conjunto de trabalhos filosóficos recentes baseia-se nessa idéia para sugerir que sujeitos racionais só estariam dispostos a delegar ao governo uma autoridade limitada.

Hobbes aparentemente reconheceu o perigo que a formação da reputação colocava para a sua teoria e corrigiu o seu conselho aos Tolos na edição de 1668 em latim do Leviatã. ${ }^{9}$ Então, nos parece que ele estava engajado em uma descrição alternativa do estado de natureza. Trabalhos recentes de teoria dos jogos sobre jogos não-cooperativos são úteis em mostrar quanto trabalho tem de ser feito para recuperar a credibilidade da descrição de Hobbes sobre a soberania ilimitada. Essa descrição é plausível apenas na medida em que os agentes racionais no estado de natureza considerassem que equilíbrios cooperativos no estado de natureza são muito difíceis de achar ou sustentar. Em condições desse tipo, deve ser verdade, por exemplo, que a formação da reputação não é possível seja porque o jogo não pode ser repetido entre jogadores, porque os outros não podem observar os resultados dos acordos contratuais, seja porque os agentes não sejam capazes de observar cada uma dessas características. Cada encontro deve ocorrer em locais isolados e entre estranhos, ou ao menos entre indivíduos com baixa probabilidade de se encontrarem novamente. Se essa é uma construção plausível do estado de natureza, e que fundamentos nós temos para supor que as interações seriam como essa descrição, é um ponto do qual depende a plausibilidade da justificação de autoridade contida no Leviatã.
É claro que argumentos a favor dos horrores do estado de natureza, se bem-sucedidos, acabam com a questão de se os agentes hobbesianos seriam capazes verdadeiramente de contratar entre si a instituição do soberano e sair do estado de natureza. Se os contratos bilaterais são impossíveis, por que deveríamos pensar que um contrato multilateral amplo seria mais facilmente negociado e bem-sucedido? Entretanto, se esse argumento está correto, é menos significativo para o projeto de Hobbes do que se considera comumente. O principal interesse de Hobbes está em produzir uma justificativa para a autoridade política em um mundo em que essa autoridade realmente existe. Se a sua teoria é ou não é capaz de dar conta da criação dessa autoridade no estado de natureza nos parece de conseqüências secundárias. ${ }^{10}$

Suponhamos, por exemplo, que a sua teoria não conseguisse dar conta dessa tarefa. Suponhamos também que ele, como Rousseau, tivesse de se apoiar em algum mecanismo, como a instituição do "legislador", para propor a criação da autoridade política e que o aparecimento de uma criação desse tipo fosse problemático, e portanto que a criação da autoridade política depois de uma revolução, digamos, fosse incerta. Parece que uma situação como essa teria o efeito de provocar um retorno para o estado de natureza ainda mais perigoso e portanto mais custoso para os agentes hobbesianos do que seria se eles pudessem predizer, com confiança, uma rápida saída do estado de natureza (através da criação de um soberano), e poderia portanto prover uma razão adicional para apoiar a autoridade política existente. Nesse sentido, ironicamente, a fragilidade do "contrato" social que institui o soberano parece servir aos propósitos teóricos de Hobbes.

\section{Desejos racionais: a construção dos objetivos da boa vida por Aristóteles}

Enquanto Hobbes estava centralmente preocupado em mostrar como agentes racionais com certos tipos específicos de desejos (autopreservação) iriam interagir no estado de natureza, as preocupações de Aristóteles estavam focadas nos tipos de desejos que os agentes racionais deveriam 
ter. Em nossa interpretação, ter desejos não é uma questão de escolha da mesma forma que entrar ou não entrar em uma convenção hobbesiana. Desejos são obtidos ou mantidos de uma forma diferente. Eles regulam a escolha das ações, no justo sentido que nosso requisito de consistência expressa, e são anteriores às ações, em um sentido ontológico. É incerto que algum comportamento possa algum dia se transformar em ação de um agente, a não ser que possa ser descrito como a serviço de preencher algum desejo daquele agente. Mas Aristóteles pensa os desejos como se estivessem de alguma forma sob nosso controle racional. Nesse sentido, temos algum tipo de responsabilidade sobre os nossos desejos. ${ }^{11}$

Que tipo de controle é esse? Aristóteles podia estar defendendo a presença de um mecanismo psicológico. Poderia ser o caso de que, agindo sobre certos desejos, pudéssemos fortalecê-los de alguma forma; não imediatamente, talvez, mas depois de um certo tempo. Se quando desejamos chocolates nós tendemos a comer chocolates, meu desejo imediato de chocolates é preenchido, mas a minha tendência de querer chocolates de tempos em tempos é fortalecida. Isso pode ser verdade porque comendo muitos tipos de chocolates eu desenvolvo uma apreciação sutil das nuanças do chocolate - esse tipo evoca o sabor de café, aquele sugere cerejas pretas, aquele último, as folhas caídas no chão da floresta - que aumenta os prazeres estéticos e intelectuais de comer chocolate. Se eu pudesse simplesmente evitar me agradar com chocolate por um período, a força da minha ânsia por chocolate provavelmente se atenuaria. Então, nesse tipo de psicologia, as ações são o que é escolhido, não os desejos. Mas escolher certos tipos de ação pode ter o efeito de reforçar ou enfraquecer desejos, e é esse efeito secundário que será uma razão adicional para escolher ou me abster da ação. Se essa é a psicologia envolvida, e se nós estamos cientes disso, podemos nos considerar responsáveis por nossos desejos, já que cabe a nós escolher se levamos em conta o efeito secundário citado acima. ${ }^{12}$

Embora a questão seja mais complicada do que essa situação sugere, essa idéia parece captar a noção de que podemos ser responsáveis por criar e sustentar nossos desejos. Aristóteles distingue fazer a coisa certa (ações corretas) de fazer a coisa certa pelo tipo correto de razões — fazer a coisa certa porque você é do tipo de pessoa que quer fazer a coisa certa. Ele distingue entre alguém que é comedido e faz boas ações porque deve de alguém que ama fazer a coisa certa e faz boas ações de uma maneira não conflituosa. O ponto da sua teoria ética é levar as pessoas que querem agir bem a desenvolver o tipo certo de caráter - ter o conjunto certo de desejos e preferências. Para ele, ter o tipo certo de caráter pode ser aprendido e o caminho para o aprendizado é "de fora para dentro":

[...] pelos atos que praticamos em nossas relações com os homens nos tornamos justos ou injustos; pelo que fazemos na presença do perigo, e pelo hábito de sentir medo ou ousadia, nos tornamos bravos ou covardes. O mesmo se pode dizer com relação aos apetites e sentimentos de raiva: alguns homens se tornam de bom temperamento e comedidos, outros auto-indulgentes e irascíveis, se comportando de uma forma ou de outra em igualdade de circunstâncias. Então, resumindo, estados de caráter emergem de atitudes parecidas com eles. Essa é a razão de as atividades que nós exibimos terem que ser de um certo tipo; é porque os estados de caráter correspondem às diferenças entre esses. Não faz pouca diferença, portanto, se nós formamos hábitos de um tipo ou de outro desde a nossa infância mais precoce; faz muita diferença, ou ainda, faz toda a diferença. ( Ética a Nicômano, Livro 2, cap. 1)

Essa passagem sugere que ter bom caráter os desejos e sentimentos corretos - pode ser conseguido aprendendo primeiro a se comportar corretamente. Notemos que ter bom caráter consiste em duas coisas separadas: primeiramente, ter o tipo correto de sentimentos e desejos, e então fazer ações corretas de forma a ir ao encontro daqueles desejos. Mas, é claro que isso é curioso. Como, antes de ter o conjunto apropriado de desejos e emoções, podemos ser levados a executar as ações corretas? É aqui que surge com destaque a importância de ter sido treinado ou levado a ter bons 
hábitos. A chave para esse desenvolvimento ou educação é encontrada na idéia de hábito de Aristóteles: "as virtudes morais vêm do hábito, de onde o seu nome (ethike) é formado a partir de uma leve variação da palavra ethos (hábito)." (Ética a Nicômano, Livro 2, 1). Portanto, controles sociais ou exteriores fixam a escolha da ação, ao menos em muitas situações de escolha moral ou ética. Comportando-nos corretamente, podemos aprender a amar fazer a coisa certa (alinhando nossos sentimentos e desejos com a ação correta). Então podemos começar a falar em ações corretas no sentido certo (como um exercício de virtude).

Essa história psicológica é simples demais para captar a noção de Aristóteles de como as pessoas podem ser ou se tornar virtuosas. Não é plausível que possamos adquirir hábitos suficientes para guiar nossas ações em todas as circunstâncias concebíveis de escolha moral de forma a que a psicologia pudesse nos guiar automaticamente para sermos virtuosos. Na melhor das hipóteses, a sociedade pode nos prover direcionamento claro apenas nos casos mais fáceis. Escolhas mais difíceis requerem profundidade em raciocínio prático que alguém que não tenha virtude (os desejos e sentimentos corretos) não será capaz de executar. A idéia aristotélica tem portanto um elemento dialético. Primeiramente você começa com hábitos bons e simples; em seguida você aprende a amar fazer as coisas nesses casos mais claros (de alguma forma começando a desenvolver o tipo correto de desejos e sentimentos); então você usa esses novos desejos e sentimentos para descobrir ações corretas nos casos mais difíceis, e pode continuar desenvolvendo os desejos corretos a partir daí indefinidamente. Isso proporciona um esboço de como é possível psicologicamente determinar ou "escolher" os seus desejos e sentimentos sem realmente escolhê-los diretamente. Desenvolver o tipo correto de desejos é um tipo de objetivo de ordem superior que Aristóteles nos leva a ter. Nós queremos, ao menos aqueles de nós que são bem criados, aprender a ser virtuosos e reconhecer que os passos para a educação moral seguem a dialética prática enunciada acima. Então, escolher não entrar nessa dialética — seja porque não se adotam as ações corretas, mesmo que elas sejam meramen- te recomendadas pelo hábito, seja por não aprender a amar essas ações da forma certa - é condenável. Nesse sentido, somos responsáveis por quem somos, assim como pelos desejos e sentimentos que temos.

Aristóteles apresenta, portanto, um tipo de teoria endógena de formação de preferências, na medida em que ele indica como desejos e sentimentos podem ser construídos e desenvolvidos. Entretanto, da forma delineada até agora, a questão está incompleta. Aparentemente, apenas se as pessoas começam com bons hábitos e a partir daí seguem dialeticamente elas se tornarão virtuosas no final, no sentido de formarem os desejos corretos. Embora os hábitos joguem um papel importante em fazer essas coisas acontecerem, Aristóteles não pensava que eles fossem suficientes para produzir pessoas virtuosas. Para isso se requer uma maior condução, o que Aristóteles chama de sabedoria prática, ou a capacidade de deliberar também a respeito de fins:

[...] a marca de um homem com sabedoria prática é conseguir deliberar bem sobre o que é bom e vantajoso para si próprio, não em algum aspecto particular, isso é, sobre que tipo de coisas conduzemà saúde eà força, mas sobre que tipo de coisas conduzem a uma vida boa em geral. Isso fica claro pelo fato de que creditamos positivamente os homens com sabedoria prática em algum aspecto particular quando eles raciocinam bem objetivando algum bom objetivo, que é um daqueles que não é objeto de nenhuma arte. Como conseqüência, em um sentido mais geral, um homem que é capaz de deliberar também tem sabedoria prática. (Ética a Nicômano, Livro 6, cap. 5)

O problema é que há inúmeros desejos por boas coisas e essas são muito diferentes e podem ser conflituosas entre si. Nós queremos comida excelente, bons vinhos, sexo prazeroso, belos carros, ópera, teatro e também um monte de outras coisas boas. A busca de cada uma dessas coisas boas pode, em algumas circunstâncias, dificultar ou impedir a obtenção de outras. Como desejos tão diversos como esses podem ser maximizados? Evidentemente, o que se necessita é ajustar ou 
harmonizar de alguma forma nossos desejos por várias coisas, de maneira que a sua satisfação possa se tornar compatível.

Não há realmente nenhuma forma de maximizar de maneira genuína preferências incomensuráveis, a não ser que possamos colocá-las em uma única escala ou métrica. Isso é, a não ser que elas sejam de alguma forma comensuráveis. Mas a questão da mensuração não é idêntica à da redução. Mesmo se conseguirmos estabelecer um padrão único — o bem, ou a vida boa — que seja o nosso objetivo último, cada qual dos bens parciais e diversos (comida, vinhos, carros velozes) continua sendo um bem e sendo desejável para nós. Embora possamos querer a felicidade ou uma vida boa, parte do prazer de ter essa vida é na verdade composto por acesso a boa comida e bons vinhos. A vida boa não é separável de seus constituintes. A idéia de que o bem parcial continua desejável pode ser vista na consideração de Aristóteles das pessoas que são akratic - que têm conhecimento do que deveriam fazer, segundo o bem, mas escolhem seguir algum bem parcial, ao invés de perseguir o bem geral — e da pessoa comedida que sabe o que é bom e resiste à tentação genuína de perseguir outros bens parciais. A pessoa virtuosa sabe o que o bem requer e, embora ela aprecie e valorize os bens parciais, não é tentada a se desviar do bem. Então Aristóteles afirma que a harmonização dos bens parciais envolve deliberação (a aplicação da sabedoria prática) sobre o que a vida boa requer. Nesse processo, quem delibera desenvolve ou modula os seus desejos por esses bens parciais de forma a que eles se harmonizem com os requisitos gerais de se viver uma vida boa e virtuosa.

É nesse ponto que nós podemos começar a ver alguns problemas teóricos com a teoria de Aristóteles. Podemos deixar de lado, por enquanto, a psicologia positiva que direciona endogenamente as preferências. Parece plausível, em termos teóricos gerais, aceitá-la como hipótese de trabalho. Mas o que é mais controverso é a noção de que seja realmente possível alcançar a harmonização que se supõe necessária para o exercício da deliberação ou sabedoria prática. A harmonização funcionaria apenas se os valores parciais fossem de alguma forma comensuráveis. Se eles não são, a harmonização torna-se um problema de bem-estar "social" intrapessoal: ${ }^{13}$ como valores diversos podem ser agregados em uma concepção resumida de bem? Ou, para colocar a questão em termos arrownianos, se existe para o indivíduo uma noção coerente de bem que é conectada com bens parciais incomensuráveis de uma forma regular (expressa nos axiomas de Arrow), não é verdade que o teorema de Arrow nos afirma que um dos bens parciais determina, ao fim e ao cabo, o bem geral?

Sem sabermos mais sobre como os bens parciais e o geral podem se conectar, é impossível responder à questão. Mas parece claro que se Aristóteles está compromissado com alguma forma de comensurabilidade, entendida como uma propriedade da boa vida para um indivíduo (ao menos no nível do indivíduo), então há um sério problema com a racionalidade intrapessoal necessária para alcançá-la. O que mantém a noção de sabedoria prática de Aristóteles em um mundo que aceita o pluralismo de valores?

É claro que isso deixa de lado as questões pessoais. Partindo da premissa de que a sua audiência tinha bons hábitos, Aristóteles parece assumir a disponibilidade de um padrão de ação pública relativamente claro. É verdade que esse é apenas um ponto de partida e ele provavelmente resolveria a questão afirmando que existe apenas um conjunto limitado de questões nas quais o consenso público existe. Ainda assim, a educação moral molda presumidamente nossos valores e comportamentos, todos juntos e não separados. Então, por que razão devemos pensar que isso seria verdadeiro, a não ser que a sabedoria prática fosse guiada por um mesmo bem final? Não há razões plausíveis para acreditarmos que não há muitas formas de viver a boa vida e vivermos em um mundo de razoável pluralismo? Isto é: de uma perspectiva moderna, a concepção de sabedoria prática de Aristóteles nos parece rígida demais, talvez até mesmo inaceitável. Será que ela pode ser tornada mais maleável de forma a nos ser útil?

A resposta do próprio Aristóteles parece se apoiar no fato de que nós, como animais políticos, vivemos juntos em comunidades que governam a 
si próprias. As políticas que essas comunidades adotam e seguem são a ocasião para desenvolver a sabedoria prática em Ciência Política, e para Aristóteles nós temos realmente interesses comuns. Algumas democracias deliberativas modernas nos pressionam, por essa razão, a começar a desenvolver práticas deliberativas nas comunidades locais relativamente homogêneas que possam nos ajudar a compartilhar uma concepção comum de bem.

\section{Rousseau: moldando crenças para a ação coletiva}

A teoria do contrato social de Rousseau é cognitiva ou epistêmica, no sentido de desenhar instituições que, com uma certa probabilidade, resultem na formação das crenças coletivas corretas. O momento da "constituição" de uma comunidade política permite a ele encontrar as crenças substantivas corretas sobre como deveriam ser as leis. Essas crenças são sobre coisas de alguma forma externas aos agentes particulares que fazem a sociedade, de forma similar às crenças a respeito do mundo natural. Espera-se que se alguns ou todos esses agentes fossem trocados (e todos o serão pela morte, imigração ou senilidade), as melhores regras para a comunidade permaneceriam imutáveis. Ao menos é isso que Rousseau parece expressar em seus exemplos de poucas e imutáveis leis de repúblicas bem governadas.

Mas como é hoje amplamente sabido, instituições desenhadas apropriadamente geralmente não são suficientes para preencher determinados resultados coletivos, qualquer forma que esses resultados tomem, isto é, se elas são regras ou ações públicas como na teoria das crenças ou julgamentos coletivos de Rousseau. Isso ocorre porque estruturas estratégicas complexas geralmente têm vários equilíbrios e, com freqüência, o conjunto de resultados que podem ser alcançados por algum equilíbrio também é bastante grande. Então, na medida em que Rousseau está tentando recomendar instituições que tendam a produzir bons julgamentos, suas preocupações devem ser entendidas como centradas em crenças estratégicas: crenças a respeito do que os agentes específicos na sociedade estão fazendo de verdade quan- do realizam julgamentos coletivos. São essas crenças que permitem aos membros de uma comunidade bem governada coordenar as suas ações apropriadamente para regular de maneira eficiente a sua vida pública. Ambos os tipos de crenças devem ser vistos como endogenamente produzidos, mas eles mantêm uma relação particular entre si. Para que as crenças substantivas corretas sejam formadas, é necessário dispor das crenças estratégicas apropriadas. Nesse sentido, as crenças substantivas dependem das crenças estratégicas. Discutiremos cada tipo de crença, começando pela descrição do geral, tendo como objetivo formar as crenças substantivas corretas.

Um grupo ou comunidade de pessoas concorda em ter um governo porque tem objetivos comuns ou partilhados e descobre que esse propósito comum é tarefa das instituições políticas. Nas palavras de Rousseau:

O laço da sociedade é o que existe em comum entre esses diferentes interesses, e se não houve um ponto onde todos os interesses eram idênticos, não poderia ter havido sociedade. ( $O$ contrato social, Livro II, cap. I)

A vontade de todos os membros do Estado é a vontade geral, através da qual eles são cidadãos e livres. Quando se propõe uma lei na assembléia do povo, o que se lhe pergunta não é exatamente se ela aprova ou rejeita a proposta, mas se ela está de acordo com a vontade geral, que é a sua vontade. Cada qual, dando o seu voto, coloca a sua posição sobre aquele ponto, e a vontade geral é declarada pela contagem dos votos. Quando, portanto, uma vontade que é contrária à minha prevalece, ela só prova que eu estava errado, e o que eu pensava que fosse a vontade geral não o era. Se minha opinião particular prevalecesse, eu teria feito o que não desejava e não teria sido livre. ( O contrato social, Livro IV)

A vontade geral não é composta, entretanto, dos propósitos comuns ou do bem público em uma comunidade. Mesmo se todos na sociedade se beneficiassem de uma proposta específica de política, essa política não seria necessariamente parte da vontade geral. Para que possa ser classificada 
nessa categoria, uma política deve satisfazer também um requisito adicional: que trate todos os cidadãos igualmente. Nesse sentido, a obrigatoriedade de cada cidadão se engajar em um perigoso serviço militar quando selecionado pelo Estado poderia ser parte da vontade geral (já que todos se beneficiariam se esse requisito fosse colocado em prática). Uma política desse tipo trata todos de maneira igual e é benéfica a todos. Esses requisitos são, para Rousseau, os únicos candidatos possíveis a leis genuínas.

[...] a lei se preocupa com os indivíduos do Estado considerado como um todo, assim como com ações consideradas como puramente abstratas. (O contrato social, Livro II, cap. 6)

Outros tipos de comandos - que certos proprietários paguem uma contribuição especial ou que os padeiros não trabalhem mais do que 10 horas por dia, por exemplo — não podem ser expressões da vontade geral, não importa quantas pessoas os apóiem, e portanto não podem ser leis genuínas. Essas ordens podem, entretanto, ser de interesse público e podem ser aplicadas como ordens administrativas. ${ }^{14}$ A idéia-chave é que decisões ad hoc - que não satisfazem o critério da generalidade - não são a preocupação da vontade geral. ( ibidem)

A noção de vontade que Rousseau apresenta em sua teoria da vontade geral é normativa: a vontade que você deveria ter sob certas circunstâncias e não necessariamente a vontade que realmente o move para a ação. Na maior parte das nossas atividades somos movidos parcial ou completamente por nossas vontades privadas. Podemos não ser movidos pela vontade geral por três razões. Primeiramente, a vontade geral pode não ser aplicável a uma ação específica — pode não interessar ao público se fazemos as coisas de uma forma ou de outra na maior parte das nossas vidas domésticas. Em segundo lugar, nós podemos não conseguir perceber a vontade geral, confundindo-a com o que é do nosso interesse privado. Finalmente, podemos perceber a vontade geral mas não conseguir agir segundo ela, preferindo, ao contrário, seguir o nosso próprio curso privado de ação.
Rousseau, portanto, está preocupado com dois problemas políticos. Primeiro, descobrir uma sociedade viável — uma sociedade que tenha propósitos comuns em quantidade suficiente para realmente constituir uma vontade geral (essa é uma questão de interdependência e contigüidade, entre outras coisas) e que satisfaça outros requisitos técnicos (seja de tamanho apropriado de forma a que a tarefa epistemológica de descobrir esses propósitos comuns seja possível, e talvez que a comunicação seja suficientemente densa para permitir que as coisas corram bem etc.). Uma comunidade como essa pode decidir entrar em um acordo para formar um Estado, no qual cada pessoa abra mão de seus direitos naturais em troca de direitos civis garantidos pelo Estado. O segundo problema político enfrentado por Rousseau é o desenho de um conjunto viável de instituições estatais para tal sociedade - instituições que possam trabalhar de forma confiável para descobrir a vontade geral e permitir que as vontades de cada um de nós sejam compatibilizadas com a vontade geral. Em princípio, essa última tarefa política tem dois componentes: primeiro, os indivíduos devem ser capazes de descobrir nossos propósitos comuns. Essa é, para Rousseau, a tarefa legislativa e é, como nós sugerimos, principalmente epistêmica: cada um de nós passa a encarar a vontade geral como parte da sua própria vontade. Em segundo lugar, devemos garantir que cada um de nós faça a sua parte na construção da nossa própria vontade geral, mesmo quando essa entra em conflito com outros componentes das nossas vontades individuais. Essa é, parcialmente, a tarefa da educação e da "religião", e parcialmente a tarefa da magistratura, que pode, ocasionalmente, precisar forçar o cumprimento da vontade geral contra indivíduos recalcitrantes: "O cidadão dá o seu consentimento para todas as leis, incluindo aquelas que são aprovadas apesar da sua oposição, e mesmo aquelas que o punem quando ele ousa romper com alguma delas." ( O contrato social, Livro IV).

Esses dois problemas políticos levantam duas questões psicológicas. A primeira é cognitiva: como as pessoas de uma sociedade podem ser levadas a ver o que elas têm em comum? Que instituições permitirão a elas colocar de lado os 
seus próprios interesses e preocupações pessoais durante um tempo suficientemente longo para deixá-las discernir o que elas têm em comum? A segunda questão é de motivação: mesmo se as pessoas (ou, em algum grau, a maioria das pessoas) podem absorver o interesse público de forma confiável, como elas podem ser induzidas a querer alcançá-lo, e portanto a agir sobre ele? Parece-nos que Rousseau concorda com Aristóteles que essa segunda questão é muito difícil, ao contrário de Sócrates, que pensava que uma vez que uma pessoa captava o seu interesse, ela não faria outra coisa do que persegui-lo.

A resposta de Rousseau à primeira questão envolve dois pontos. Apenas algumas afirmações podem se qualificar como candidatas a expressões da vontade geral. Essas afirmações devem ser gerais no seu tratamento dos indivíduos — indivíduos devem ser tratados simétrica ou igualmente - e, portanto, propostas que tratem diferentemente pessoas ou grupos não podem ser leis. Isso fornece um teste público formal da possibilidade de uma proposta tornar-se uma candidata plausível à vontade geral. ${ }^{15} \mathrm{Em}$ segundo lugar, ele identifica o Legislativo como sendo o poder soberano, que é de todas as pessoas. Cada pessoa tem um pequeno acesso, embora reduzido, à vontade geral, e apenas os membros de uma assembléia são capazes de tirar vantagem dessa informação dispersa. Em uma formulação famosa, o autor rejeita a delegação do poder legislativo a um corpo representativo porque os seus membros teriam interesses próprios separados da vontade geral. Uma assembléia seria inevitavelmente ineficiente em termos de informação e enviesada com respeito aos interesses. O poder legislativo - o poder de declarar a vontade geral - , portanto, pôde ser exercido pelo povo apenas na Atenas clássica.

Mas enquanto se conhece bem a desconfiança de Rousseau acerca dos representantes eleitos (para propósitos legislativos), fica clara também a sua desconfiança dos membros da assembléia. Nesta, vários subgrupos ou alianças entre facções podem formar e apresentar vontades particulares como se fossem gerais. Portanto, permanece até certo ponto um mistério como o poder soberano pode ser exercido, dada a crença de Rousseau de que a comunicação entre as pessoas também tende a levar a percepções distorcidas.

\begin{abstract}
Se, quando o povo, bem guarnecido de informações adequadas, tomar suas deliberações, os cidadãos não tiverem comunicação entre si, a soma geral das pequenas diferenças sempre dará a vontade geral, e a decisão sempre será boa. Mas quando emergem as facções, e as associações parciais são formadas à custa da grande associação, a vontade de cada uma das associações se torna geral com relação a seus membros, enquanto se torna particular com relação ao resto do Estado: pode-se então dizer que não existem mais tantos votos quanto homens, mas apenas tantos quanto as associações. As diferenças se tornam menos numerosas e dão um resultado menos geral. Por fim, quando uma dessas associações é grande o suficiente para prevalecer sobre todas as outras, o resultado não é mais a soma da pequenas diferenças, mas a diferença simples. Nesse caso, não há mais uma vontade geral, e a opinião que prevalece é puramente particular. É portanto essencial, se se pretende que a vontade geral seja expressa, que não haja sociedade parcial dentro do Estado, e que cada cidadão pense somente os seus próprios pensamentos: que era, na verdade, o único e sublime sistema estabelecido pelo grande Licurgo. ( O contrato social, Livro II, cap. 3)
\end{abstract}

Rousseau claramente considera essencial que a informação seja acessível a cada cidadão para que esses sejam aptos a descobrir os propósitos comuns. Também é claro que se deve evitar que os partidos, grupos de interesse e facções tenham qualquer papel nas deliberações. Isso é necessário por duas razões. Primeiramente, eles têm interesses diferentes daqueles do conjunto do povo e portanto irão enviesar o processo para longe da descoberta dos verdadeiros interesses comuns. Em segundo lugar, ao agrupar pessoas, eles diminuem a quantidade de votos independentes que o autor acredita que se cancelariam mutuamente na descoberta da vontade geral. Isso sugere que as votações, na presença de facções, serão ineficientes na descoberta da vontade geral, no sentido de produzirem uma variância elevada de- 
mais. Se esse segundo raciocínio antecipa a descoberta de Condorcet em seu famoso teorema, Rousseau o complementou com uma idéia mais comumente atribuída a Madison, ou talvez a Hume:

\begin{abstract}
Mas se há sociedades parciais, é melhor que haja tantas quanto possível e que se impeça que elas sejam desiguais, como foi feito por Sólon Numa e Sérvio. Essas são as únicas precauções que podem garantir que a vontade geral seja sempre ilumina$\mathrm{da}$, e que o povo não se engane em nenhum sentido. ( O contato social, Livro II, cap. 3)
\end{abstract}

Essas precauções de segunda opção deveriam reduzir tanto o enviesamento, quanto as ineficiências (informacionais) das "deliberações" públicas. Entretanto, deliberações talvez seja um termo estranho para o processo legislativo em Rousseau. Em alguns momentos de O contrato social ele parece estar inclinado a proibir as comunicações no interior dos subgrupos durante o processo de deliberação, e até mesmo a possivelmente limitar os discursos na própria assembléia, receando que qualquer comunicação poderia levar à formação de interesses parciais. Ou talvez, ecoando os demagogos atenienses e os retóricos romanos, ele temesse que a audiência pudesse ser facilmente encantada por apelos quiméricos. Acreditamos que a sua visão sobre deliberação não é assim tão simples. É verdade que Rousseau acreditava que o povo tinha dificuldades de perceber e ser movido pela vontade geral, comparado ao apelo dos seus interesses particulares. E se os homens acabavam desenvolvendo interesses de facção, essas vontades tinham maior poder de impulsioná-los que a vontade geral. Então, é uma questão de grande preocupação para Rousseau conseguir instituições e normas - incluindo normas de deliberação que permitissem que um pequeno traço da vontade geral pudesse ser amplificado pela ação coletiva. Se instituições e normas desse tipo fossem construídas, haveria pequeno risco na deliberação.

Enquanto um conjunto de homens se reconheça como constituindo um único corpo, eles têm apenas uma vontade, que se relaciona com a sua preservação comum e com o bem-estar de todos.
Quando isso acontece, as fontes do Estado são vigorosas e simples, os seus princípios claros e diretos. Ele não está envolvido com interesses confusos ou conflituosos. O bem comum está em todo o lugar em evidência e para percebê-lo é necessário apenas bom senso...

Um Estado assim governado precisa apenas de algumas leis, e quando se considera necessário promulgar novas, a necessidade será óbvia para todos. Aquele que na verdade vocaliza as propostas não faz mais do que colocar em palavras o que todos já sentiram, e nem a intriga nem a eloqüência são necessárias para garantir a passagem de uma lei que cada um já se sente determinado a apoiar, tão rápido quanto ele tem a garantia de que seus pares o seguirão em seguida. ( $O$ contrato social, Livro IV, cap. 1)

Em um Estado construído apropriadamente, portanto, a deliberação é uma questão de articular a necessidade de uma nova lei (identificando a vontade geral), encontrar uma forma apropriada de expressá-la, e coordenar a ação de outros cidadãos para garantir a sua aplicação. O fato de o Estado ser bem construído significa que cada qual tem uma visão minimamente clara da vontade geral, e por essa razão Rousseau espera que os debates sejam breves. A maior parte da discussão será dedicada a conseguir a formulação correta da lei sobre a qual todos concordam e que ela seja apropriada como uma expressão da vontade geral. Em um Estado como esse, não há necessidade de impor limitações especiais sobre o debate e a argumentação. As pessoas compreenderão que a matéria-prima apropriada para a vontade geral (da lei) é geral, estarão bem motivadas para vocalizar legislação apropriada em termos gerais, e não se sentirão tentadas a perseguir vantagens individuais sob o manto da produção das leis.

É em Estados construídos de forma pobre que os conflitos de interesse emergem: "os homens não mais falam uma única voz, não mais a vontade geral é a vontade de todos. As contradições aparecem, as discussões surgem, e não se permite que passe sem oposição nem mesmo o melhor conselho." (O contrato social, Livro IV, cap. 1). Nesses Estados, os processos deliberativos podem ser 
perigosos, pois a vontade geral é "[...] subordinada a outras vontades que se sobrepõem a ela. Cada um, separando o seu interesse do interesse de todos, vê que a separação não pode ser completa, embora a parte que ele jogue no dano geral pareça nada para ele comparada com o bem exclusivo que ele tenta se apropriar." ( ibidem).

Rousseau cita o exemplo da introdução do voto secreto em Roma, que pretendia colocar um limite à venda de votos e a outras perversões das deliberações públicas. Ele reconhece que a necessidade do voto secreto era lamentável — era muito melhor quando os romanos tinham a integridade de se levantar e se engajar em deliberação honesta e, ao final, anunciar os seus votos honestamente. Mas, na época em que o voto secreto foi adotado, esses dias virtuosos tinham passado e a preservação da República requeria uma regulamentação muito mais restritiva da deliberação pública. ${ }^{16}$

Fica claro, a partir dessa discussão, que a necessidade de regular a deliberação deve-se à imperfeição das instituições e normas de deliberação, e não a nenhuma dificuldade inerente à idéia de deliberação sobre ações públicas. Em Estados mal construídos, Rousseau percebia o que nós chamaríamos nos dias de hoje de problemas de ação coletiva. As pessoas buscam seus próprios interesses ao invés do bem público porque o efeito individual de contribuir para a produção do bem público é muito pequeno ou negligenciável. Em um Estado ideal, essas motivações autodirecionadas desapareceriam de alguma forma. Como o autor não afirma como isso poderia ser alcançado, parece sugerir a direção da autocontenção moral e interna (virtude ou espírito público) e possivelmente também das sanções sociais.

Nessa interpretação, o problema de construir instituições e normas públicas boas é similar ao de se encontrar formas de garantir o comportamento cooperativo em um jogo repetido com a estrutura do dilema do prisioneiro. Em termos modernos, há vários equilíbrios possíveis para jogos desse tipo, a maioria dos quais correspondendo ao que Rousseau descreveu como envolvendo a busca egoísta de vantagens privadas por alguns ou todos os indivíduos, ou então refletindo a procura por alguns grupos de vantagens enviesadas em sua direção ou da sua facção. É esse tipo de equilíbrio que Rousseau gostaria de eliminar. Ele afirma, na verdade, que o equilíbrio cooperativo simétrico é o único que se pode considerar como expressão da vontade comum. A simetria é requerida pelo fato de a vontade geral se aplicar a todos igualmente, e o caráter cooperativo advém do requisito de que se busquem propostas públicas ou compartilhadas.

Como esse resultado pode ser alcançado? Em termos modernos, issoé, em parte, uma questão de estruturar a política de tal forma que todos os cidadãos tenham as crenças estratégicas corretas: crenças que os levem a agir de tal forma que a simetria dos resultados esteja garantida. Mas o avanço dessa análise política comparativa está em mostrar que uma das formas de diferenciação entre os Estados está no padrão de atividades públicas em que os seus cidadãos se engajam. O autor identifica apenas alguns momentos históricos nos quais as repúblicas exibiram as virtudes coletivas apropriadas e a legislação satisfez amplamente a sua condição de simetria — no início da República Romana, em Esparta e em Gênova. Mesmo nesses casos, os Estados ficaram longe do Estado ideal em inúmeros aspectos. Mas Rousseau também apela para algo que nós chamaríamos hoje de argumento de "refinamento". O seu argumento de que a vontade geral será simétrica é uma hipótese que pode ser empregada publicamente e testada em deliberações concretas. As únicas propostas que atrairão o apoio público são as que satisfazem esse teste, eliminando, conseqüentemente, a maior parte dos equilíbrios possíveis.

\section{Conclusão}

Teóricos da política tipicamente se apóiam em alguns conceitos do que seria um ser humano racional - alguém que tem objetivos e crenças e busca escolher ações à luz desses. Mas no interior dessa idéia ampla de racionalidade como um requisito de consistência, acreditamos que Hobbes, Aristóteles e Rousseau se apoiaram eficazmente em idéias distintas do que se requer de uma vida racionalmente vivida. Sem dúvida, a maior parte das diferenças entre eles pode ser associada a suas conjunturas históricas amplamente divergentes e 
às questões políticas que os preocuparam. Mas de alguma forma todos os três estavam preocupados em discutir o que eles consideravam ser um grau perigoso de diversidade nas crenças e valores humanos. Hobbes, é claro, se preocupava que o fanatismo religioso pudesse levar as pessoas a colocarem um valor pequeno demais nas suas próprias vidas e impedi-las de ver a importância de ter um Estado bem organizado para impor o comportamento cooperativo. Aristóteles e Rousseau pensavam que os prazeres privados distraem e se imprimem de uma forma tão forte nos indivíduos que estes têm grandes dificuldades em enxergar o que têm em comum e em agir para tentar alcançar esses interesses comuns. Para cada um deles, a tarefa central da teorização em Ciência Política era descobrir como seres racionais poderiam aprender a viver uns com os outros de forma mais ou menos feliz. Para Aristóteles (em seus escritos éticos), viver uma vida assim envolvia aprender a ter desejos (e emoções) bem ordenados, que servem para fazer boas escolhas em casos difíceis de discernir. Para Rousseau, viver bem em uma comunidade envolvia aprender a ver claramente que tipos de interesses temos em comum e agir a partir dessas percepções. Todos os três teóricos acreditavam que muitos dos problemas da promoção da vida boa se relacionavam, em grande parte, com as implicações da racionalidade.

Nos dias de hoje, essa visão é controversa. A maior parte dos filósofos contemporâneos duvida (para colocar de forma branda) da possibilidade de "reduzir" a moralidade, tanto pública quanto privada, à racionalidade. Alguns afirmariam que essa redução viola a distinção estabelecida por Hume entre o ser e o dever ser. Isso seria verdade se a racionalidade fosse construída como uma teoria descritiva pura, o que nenhum dos pensadores abordados em nossa presente discussão sustentou. Mas mesmo se admitirmos que a racionalidade é um aspecto normativo, o anti-reducionismo moderno parece se basear também em uma interpretação "instrumentalista" muito difusa de racionalidade, central na teoria econômica. Concepções mais ricas de racionalidade - que tenham maior substância ética - não seriam tão vulneráveis a argumentos anti-reducionistas.

\section{NOTAS}

1 Sem querer implicar ninguém em nossas interpretações, gostaríamos de agradecer aos membros do Consenso da Washington Square (também conhecido como grupo das segundas-feiras), Brian Barry, Jon Elster, Steve Holmes, Bernard Manin, Adam Przeworski e John Roemer, pelas suas críticas generosas. Também gostaríamos de agradecer a Allesandro Pizzorno pelas discussões e críticas úteis.

2 Há, é claro, exceções a essa generalização. Jon Elster (que não se autodenominaria de teórico da escolha racional), Russell Hardin, James Johnson e (muito poucos) outros nos vêm à cabeça. Na filosofia, o campo em crescimento da filosofia política tende a adotar modelos de escolha racional, ou ao menos a considerá-los de forma muito séria. Nessa linha temos de incluir Rawls, Nozick, Guthier e as versões tardias de Jean Hampton e Greg Kavka

3 Jon Elster nos sugeriu que o mecanismo psicológico através do qual as crenças são levadas a mudar é uma forma de redução dissonante. A pessoa que procura acreditar adota um comportamento pio, ao invés de adotar uma vida de prazer e glória. É a necessidade de ter crenças que sejam consistentes com os desejos (de salvação) e com as ações (devotas) que leva à formação interna da crença em Deus. Pascal escreve sobre isso de forma provocativa: "o externo deve ser associado ao interno para que se obtenha algo de Deus, o que quer dizer que devemos nos ajoelhar, rezar com os lábios etc., de forma a que o homem orgulhoso, que não se submeteria a Deus, agora se submeta. Esperar ajuda desses externos é superstição, rejeitá-los por causa dos internos é orgulho." ( Pensamentos, 250).

4 Jon Elster considera esse tipo de pensamento ou persuasão como irracional. Nós diríamos que ele cumpre os requisitos formais da racionalidade apresentados anteriormente. Entretanto, trata-se de um comportamento peculiar, em algumas circunstâncias. Em particular, se, como no caso de Elster, o campo para se formar a crença é a ação (não perfurar), então alguém poderia dizer que isso não é suficiente para apoiar a crença. Mas se a questão é simplesmente que as crenças são consistentes com a escolha da ação e as preferências (o desejo por riqueza, nesse caso), e não são refutadas pela observação, podemos dizer que esse não é um exemplo de irracionalidade mas um fenômeno "a-racional".

5 Há um non sequitur bem no início. Não está claro que cada um tem o dever de obedecer ao soberano apenas porque a vida sem o soberano seria tão horrível. Por que cada um de nós não poderia tirar vantagens individuais, desde que não fôssemos pegos e que nossas ações não levassem ao colapso do soberano?

6 Nós discutiremos dois livros recentes: o de Jean Hampton, Hobbes and the social contract tradition (1986), e o de Gregory Kavka, Hobbesian moral and political theory (1986). Embora esses autores tratem de todo o 
conjunto dos escritos políticos de Hobbes, nós nos concentraremos apenas no Leviatã, que é o documento mais ou menos definitivo de Hobbes a respeito dos assuntos que nos preocupam.

7 Não estamos certos de que a luta ativa seja logicamente necessária para que o estado de natureza seja miserável o bastante para motivar a delegação de autoridade para um soberano. A antecipação de que um aumento de riqueza superior à necessária para a sobrevivência simples (ou imediata) causaria um desastre seria suficiente.

8 Esse não é um exemplo de irracionalidade sob o ponto de vista técnico em termos gerais, mas o é em um caso onde existam múltiplos equilíbrios, cada qual apoiado por comportamentos racionais dos jogadores. Entretanto, um equilíbrio é melhor para todos os participantes.

9 A questão crucial no texto do capítulo 15 era a seguinte. $\mathrm{Na}$ edição de 1651, Hobbes aconselhou os Tolos a cumprirem os seus compromissos se a outra parte tiver cumprido os seus primeiro, ou se eles estiverem em uma sociedade com um soberano. A frase tem sido interpretada por alguns como implicando que se, por alguma razão, uma convenção no estado de natureza é formada e se a outra parte age antes, os Tolos devem ser aconselhados a cumprir as suas partes na convenção. $\mathrm{Na}$ edição em latim, Hobbes aconselhou os Tolos que era contra a razão não cumprir os seus compromissos (agindo em segundo lugar) "se há um poder que compele à ação e se a primeira parte cumpriu o seu compromisso". Essa mudança torna mais claro que o conselho de Hobbes é dirigido a alguém situado em uma sociedade com um soberano constituído e não no estado de natureza. Essa interpretação se encaixa bastante bem com o fato de o capítulo 15 ser dedicado a descrever as leis da natureza de Hobbes, que têm a característica peculiar de não serem apoiadas em ninguém, a não ser que exista um poder de coerção. As leis da natureza são, para Hobbes, mandamentos divinos, e nesse sentido são válidas eternamente. Mas esse fato não as torna eficazes ou constituidoras de compromissos entre os seres humanos. Isso se dá por duas razões: primeiramente, não há meios garantidos para ninguém ter certeza de que realmente essas leis são válidas e, segundo, mesmo se as leis fossem de conhecimento comum, sem um poder soberano ainda não haveria razão para que os indivíduos se submetessem a elas. Por essa razão, Kavka as denomina de leis de cobre da conduta moral, ao invés de regras de ouro.

10 Samuel Pufendorf foi um dos primeiros estudiosos de Hobbes a notar que essa era a sua principal preocupação, que pode ser vista nesse trecho (parágrafo 24) do De statu hominum naturalis, de 1674, um texto que não é muito bem conhecido: "Além disso, uma consideração do estado natural dos indivíduos e sua miséria é muito útil para fazer os cidadãos amar e se devotar completamente para a preservação do Estado civil, e também para fazê-los carregar de bom grado os fardos necessários para a manutenção dos Estados. Isso porque esses encargos nada mais são do que uma pequena propor- ção dos maus que marcariam uma vida sem laços civis, situação na qual estaríamos em situação muito pior do que as condições mais duras sob os Estados. Alguém que nunca pensou sobre a miséria do estado natural carrega os fardos que os governantes impõem aos cidadãos de má vontade, como se eles fossem supérfluos, ou servissem para aborrecer as pessoas ou simplesmente para nutrir a ambição e a extravagância do governante. Em contraste, alguém que pesou corretamente a situação admite que não é mais cabível reclamar de tais fardos do que dos preços das roupas ou sapatos que protegem o corpo contra clima adverso e ferimentos. Na verdade, alguém que tenha refletido cautelosamente sobre o estado natural suportará mais pacientemente os inconvenientes desagradáveis excessivos que às vezes ele experimenta nas mãos dos governantes. Esses são na verdade casos raros da vida do Estado civil, e são contrabalançados pela ocorrência de coisas melhores. Mas no estado de natureza, os indivíduos podem esperar maus equivalentes ou piores, não apenas diariamente, mas também sem fim e medida. Além disso, um cidadão de julgamento não atribuiria, de forma alguma, esses inconvenientes às características do Estado civil em si e não ficaria conseqüentemente mais descontente com ele. Ao invés disso, ele levaria em conta a imperfeição geral dos assuntos humanos, pois embora os Estados tenham sido construídos especialmente contra os maus de uma pessoa que amedrontam uma outra - um fim que requer necessariamente o envolvimento de outra pessoa - não foi possível tomar precauções precisas o bastante para prevenir a emanação do mal ocasionalmente daquelas mesmas pessoas às quais nos submetemos para escapar das maldades humanas. Da mesma forma, alguém que tenha sopesado essas questões suporta em boa vontade qualquer inconveniente do seu status e não se sente inclinado a se revoltar contra o governo. Isso ocorre principalmente porque essas mudanças quase sempre são seguidas por outros homens ao invés de por outras práticas, e porque grande parte das mudanças em uma comunidade ocorre através de guerras civis, que podem ser consideradas como dos mais graves maus civis." (Pufendorf, 1990, pp. 134-135).

11 Uma parte da idéia de Aristóteles é familiar para os teóricos modernos da escolha racional. Se pensamos em nós mesmos como tendo desejos que podem em alguns casos ser incompatíveis, a noção de deliberação sobre desejos tem a ver com regular ou ordenar nossos desejos por coisas em relações de preferências complexas sobre estados do mundo. Então, se eu desejo tanto vinho excelente como boa saúde e desejo preencher ambos os desejos "maximamente", eu preciso antes de mais nada encontrar uma forma de encaixá-los juntos de uma forma coerente. Essa pode ser recusar o décimo copo de Burgundy no jantar.

12 Essa situação, embora simples, retrata como entendemos o papel central que Aristóteles dá a ter bons hábitos. Somente os indivíduos que foram bem criados, no sentido de terem bons hábitos, podem responder de forma apropriada à educação moral. 
13 Essa idéia parece ter sido desenvolvida originalmente por Plott e Little (1975) e, posteriormente, por Hurley (1989).

14 Em períodos de guerra, por exemplo, pode ser justificável que o Estado restrinja a minha propriedade para a defesa comum, por sobre as minhas objeções, se necessário. Essa ação não poderia ser uma expressão da vontade geral, como ilustraremos mais abaixo, mesmo que seja executada pelo interesse comum. Alguém poderia objetar esse exemplo afirmando que o Estado poderia, ao invés de agir de maneira ad hoc, formular uma regra regendo a limitação da propriedade privada em momentos de emergência nacional. Essa regra poderia, na verdade, ser parte da vontade geral. Nós concordamos. Mas isso não elimina a idéia de que mesmo uma limitação ad hoc no tipo apropriado de emergência poderia, entretanto, se justificar como sendo do interesse público, embora não fosse parte da vontade geral. Além disso, alguém poderia duvidar da possibilidade de formular uma regra geral para as limitações de propriedade que fosse adequada para todas as emergências futuras.

15 Uma noção desse tipo foi muito mais desenvolvida por Habermas, que afirma que, em um ambiente deliberativo apropriado, as pessoas seriam inibidas psicologicamente de expressar ou defender legislação de interesse limitado e privado.

16 Há várias formas pelas quais as deliberações públicas podem ser reguladas em Estados imperfeitos. Proibições de grupos de interesse e partidos políticos (se possível), o uso do voto secreto e o estabelecimento de restrições a discursos públicos estão entre as formas mais comuns desse tipo de regulação. Mas Rousseau, talvez de forma surpreendente para quem o considera um defensor do princípio majoritário de representação, também expressou suas reservas sobre o uso da regra majoritária simples quando decisões particularmente importantes estivessem para serem tomadas: "Primeiramente, quanto mais importantes e sérias as questões discutidas, mais próxima a opinião que venha a prevalecer deveria estar da unanimidade. Em segundo lugar, quanto mais o assunto em questão pedir a discussão pública, menor deveria ser a diferença prescrita entre os votos para se estabelecer uma decisão: onde uma decisão importante tenha que ser alcançada, a maioria dos votos deve ser suficiente. A primeira dessas duas regras parece estar em maior harmonia com as leis, e a segunda com as questões práticas. De qualquer forma, é a combinação das duas que dá as melhores proporções para determinar a maioria necessária." ( O contrato social, Livro IV, cap. 2). Nos parece que Rousseau sempre se referiu à " maioria" com menor precisão do que os leitores modernos colocam no termo. A passagem acima sugere que ele reconhecia a necessidade de uma gradação de maiorias e parece-nos que a necessidade para esse tipo de gradação aparece em comunidades políticas imperfeitas.

\section{BIBLIOGRAFIA}

HAMPTON, Jean. (1986), Hobbes and the social contract tradition. Cambridge, Cambridge University Press.

HURLEY, Susan. (1989), Natural reasons. Londres, Oxford Press.

KAVKA, Gregory. (1986), Hobbesian moral and political theory. Princeton, Princeton University Press.

PLOTT, Charles e LITTLE, James. (1975), "Individual choices when objects have ordinal properties". Review of Economic Studies, 42: 403-413.

PUFENDORF, S. (1990), On the natural state of men. Nova York, E. Mellen Press. 